V. M. Guliy, Dr. Sc. (Geol.-Min.), Prof., orcid.org/0000-0002-7127-7045, O.V. Kostyuk, Cand. Sc. (Geol.), orcid.org/0000-0003-2218-1757
Ivan Franko National University of Lviv, Lviv, Ukrain, e-mail:vgul@ukr.net; apxeopecypc@gmail.com

\title{
PECULIARITIES OF GEOLOGICAL-STRUCTURAL POSITION, COMPOSITION AND ORIGIN OF THE SILVER-BEARING ORES OF THE COBALT-GOWGANDA AREA (CANADIAN SHIELD)
}

Purpose. Obtaining new and generalizing previously published results of research studies on geological and structural situation, mineralogical and petrographic compositions and formation peculiarities of ores from deposits of five element formation the Cobalt-Gowganda region (Canada), and comparing it to similar deposits from other world areas.

Methodology. The research included traditional geological observations with collecting samples of various hosting rocks and ores, mineralogical and petrographic analysis of thin sections and polishes samples with ontogeny modeling of minerals formation and detection of their separate generations, determination of rocks and minerals chemical composition along with measuring their reflective power and thermo electro-motive force of sulfides. Isotopic analysis of carbon and oxygen in carbonates from the deposits has been used for genetic constructions.

Findings. The results obtained during investigations of regional geology, setting of the ore beds, mineral composition of the ores allow connecting ore mineralization formation in the Cobalt-Gowganda region with the main stages of geological development of the Abitibi greenstone belt, formation of fault systems of different order and cracks, which have promoted circulation of ore-bearing solutions enriched by different components from hosting rocks. Presence of various minerals in concrete places of ores is defined by chemical composition and structure of the initial hosting rocks.

Originality. Joint characteristic of the deposit model for five element formation in the Cobalt-Gowganda region involving different generations of the ore minerals is developed. They are characterized by various physical properties and data on isotopic composition of the carbon and oxygen from the carbonates, which differentiates them from carbonates of other genetic types.

Practical value. It is determined by obtained characteristics of the model silver deposits and their minerals of different associations, which help to estimate possible findings of the similar objects in analogical complexes of the Ukrainian Shield and surrounding territory.

Keywords: silver deposits, five element formation, Cobalt-Gowganda, Canadian and Ukrainian Shields

Introduction. Information on silver finds in Canada dates back to the Middle ages; however, large scale mining of silver and associated metals in the Cobalt-Gowganda region (Ontario Province) has been known only since the beginning of the $20^{\text {th }}$ century, when after accidental silver finding during construction of a rail way, numerous mines were found within separate districts of the modern limits of the Abitibi greenstone belt where Cobalt town grew with the population of thousands of people, hotels, pavements and other civilization adornments of those times [1]. Ores rich in silver and cobalt were located close to the surface and it was not necessary to use deep and expensive underground mines, so mining was cheap. Total amount of silver mined in 1904 was $14.5 \mathrm{mln} t$ of cobalt, and in 1910 Cobalt became one of the biggest producers of silver in the world. Output of silver in 1911 was over $937.5 \mathrm{t}$. This sharp growth of the region stopped after discovery and beginning of silver and cobalt mining from the deposits in Congo, Peru, and other world mining centers. Subsequent development of mining in the Cobal-Gowganda region had mainly sporadic character and at the end of last century the total output was minimal. Unique deposits of this region due to high grade of ores, rich mineral composition, and great traditions led it to new flourishing in the

(C) Guliy V. M., Kostyuk O. V., 2018 last decades. Numerous adits, rich in various mineral dumps, beauty of the nature of the old mining region were used to create tourist routes, when visitors may look for wonderful samples with native silver and impressible minerals without any assistance and visit renovated underground mines plunging into old spirit of "the silver Klondike", have provided for successful status of one "the most historical town of Canada".

In due course, scientific significance of the CobaltGowganda region has not decreased either, and not only due to accessibility to rich mineralogical materials, which help to discover new minerals at the present day, but as a geological reservation of specific deposits, which are regarded commonly as a five element formation. In contrast to its analogues in Europe, they do not contain uranium. The comparison of deposits of both famous regions in the Cobalt-Gowganda and Czech massive, which have similar geological and structural position of ore bodies, and ore minerals associations in general, allows understanding reasons of their metallogenic specializations differences.

Despite wide development of the Precambrian greenstone belts, in Ukraine there are only sporadical silver findings. Taking into account possibility to discover silver-bearing ores similar in composition and origin in such Precambrian formations, we used our own data and authoritative scientific literature articles on the deposits of the Cobalt-Gowganda region to conduct in- 
vestigation of the ores, and obtained results became the basis for this article.

Materials and methods of the investigation. Geological observations within the deposits of the Cobalt-Gowganda region with descriptions of outcrops, investigations of walls in the underground mines (mainly operation and museum adits for now), studying of ore samples and hosting rocks in numerous dumps and neglected quarries were involved as a basement for our investigations. Set of the selected samples was studied using traditional petrographic and mineragraphic methods with thin sections and polished samples.

To confirm the ore minerals determination we involved data on their reflection spectra with spectrum photometer (MSFP model of the "LOMO" firm) in diapason of visible spectrum of 400-700 $\mathrm{nm}$ and in near ultraviolet (up to $1200 \mathrm{~nm}$ ) and infrared (up to $250 \mathrm{~nm}$ ) parts of spectrum. The obtained results are shown in corresponding diagrams, where along the abscissa axis wave-length $(\mathrm{L}, \mathrm{nm})$ is indicated and along ordinate axis reflection coefficient of minerals in the air $(\mathrm{R}, \%)$ is shown, using also superposition of the etalon spectra.

Taking into consideration frequent occurrence of pyrite in ore formations of the Ukrainian Shield [2, 3], which are regarded as possibly analogous to the Precambrian ores of the five-element $(\mathrm{Co}-\mathrm{Ni}-\mathrm{As}-\mathrm{Ag}-$ $\mathrm{Bi}$ ) formation from the Abitibi belt, thermo-electromotive force of the pyrite was detected for their comparisons as well as determination of its conductivity types. We used the "Signal" facilities and measured at least 32 indices for each sample. To estimate homogeneity of the received data we created the histogram of data distribution.

To get information on peculiarities of the $\mathrm{C}$ and $\mathrm{O}$ isotopic compositions of carbonates from the main kinds of the ores we involved a set of samples from different deposits of the Cobalt-Gowganda, which were analyzed at the Lab of Stable Isotopes of the Institute of the Lithosphere, Russian Academy of Sciences (Moscow) under leadership of Yu. A. Borschevskii. Measurements of relative differences of the isotopic relationships of carbon and oxygen were taken with the Varian MAT250 mass spectrometer (Varian MAT, USA-FRG). The $\delta^{13} \mathrm{C}$ and $\delta^{18} \mathrm{O}$ values were determined accurate to $\pm 0.1 \%$ and $\pm 0.2 \%$, respectively in the PDB standard for $\mathrm{C}$ and SMOW standard for O. Generalized diagrams for different types of the carbonate rocks as well for the vein carbonates in coordinates of the $\delta^{13} \mathrm{C}-\delta^{18} \mathrm{O}$ were used for interpretation of the obtained data.

Peculiarities of geological and structural situation of the deposits of the Cobalt-Gowganda region. Deposits of the Cobalt-Gowganda region are located in the southern part of the Precambrian Canadian Shield, which is adjacent to the Great Lakes. Wide development of elongated greenstone belts, which are composed of big in thickness Upper Archean - Lower Proterozoic sedimentary volcanic complexes of the Huronian Super group (Kivatin, Amisk, and other formations), is an indicative feature of the geological structure of this territory (Fig. 1). Five-element formation deposits unique in rich ores with significant role of native silver were dis- covered here. The deposits are components of the great Timiskaming Province, which includes two big ore fields - Cobalt and Gowganda [1, 4, 5]. There were mined vertical veins with northern-western stretch, which are located mainly in glacial sediments (Fig. 2) conglomerates, grauwacke, and quartzite of the flat lying within lower part of the Precambrian Cobalt Series and upper part of the lying Kivatin Formation, represented by flows of basic-middle composition with intercalation of tuff-sedimentary rocks.

In some places ore mineralization is detected within lower parts of the big in thickness diabase sill Nipissing (2209 \pm 4 m.y.). Some investigators genetically relate ore mineralization to the Nipissing sill $[1,4]$.

Silver bearing veins are located higher than the diabase Nipissing sill, lower and within of its (Fig. 3) [4, 5]. Veins are sub-vertical and stretch by $15-250 \mathrm{~m}$ with thickness from 0.2 up to $20 \mathrm{~m}$. They are detected up to depths of 50-60 m, more rarely up to $100 \mathrm{~m}$ and exclu-

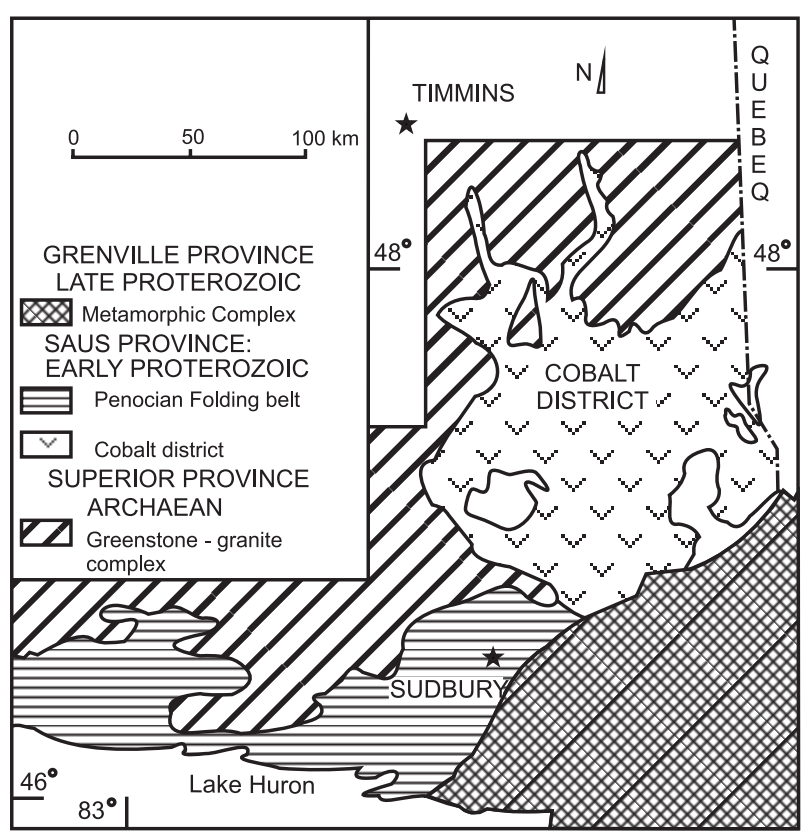

Fig. 1. Geological map of the Cobalt-Gowganda region $[1,4,5]$

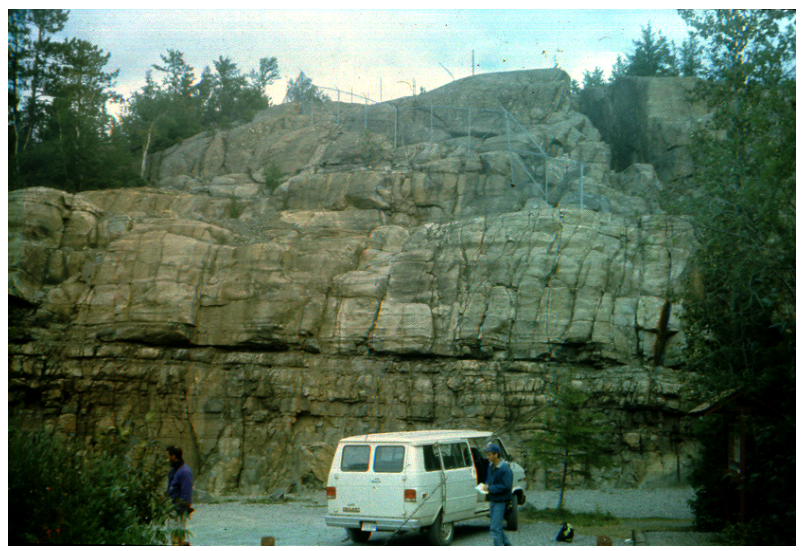

Fig. 2. Sequence of Huronian fluvial-glacial sediments in the Cobalt-Gowganda region 


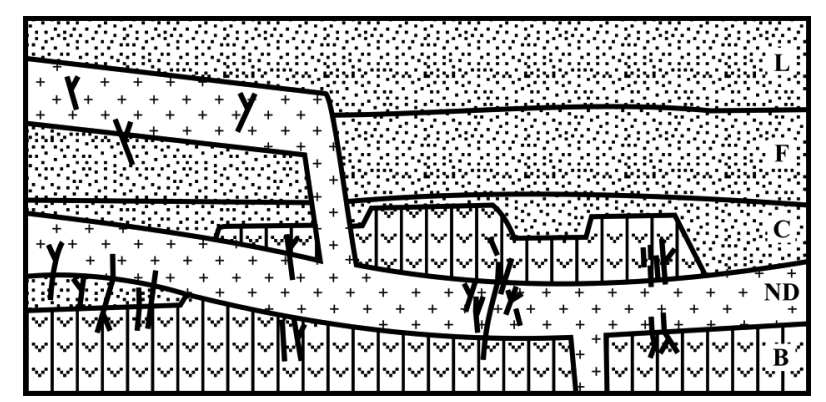

Fig. 3. Location of ore veins (solid black lines) within hosting rocks:

$L, F, C-$ Huronian formations, $B-$ Archean basement and the Nipissing diabase (ND) in the Cobalt-Gowganda region $[1,4,5]$

sively up to $450 \mathrm{~m}$. There occur separate veins as well as systems of veins in the region.

The Cobalt Lake Fault is the main ore-controlling structure of the Cobalt ore field, and is stretched by 6-7 km. Ore bodies are connected both to its short orebearing interval, and, mainly, to small cracks, which are parallel to the main fault.

Veins are developed in the cracks and create vein systems crossing and connecting in vertical and horizontal directions. Exactly these systems include the main ores volume.

Ore bodies are commonly represented by two-three and more veins as well small veins within the hosting rocks. It has been established that, primary sedimentary rocks are more conductive for crack development, and due to this their ore bodies have bigger thickness than those in the Nipissing diabase and volcanic rocks of the Kivatin Formation.

Composition and typical mineral associations of the ores. Majority of the ore-hosting faults, which are oriented concordantly to the diabase sill, is filled with small in thickness and irregular veins with very high silver grades. The main mass of the ore bodies in the Gowganda ore field is located in the upper part of the sill, where native silver veins often are developed without gangue minerals in contrast to the ore field Cobalt. Silver is distributed as a component of sulfides, antimonites, and arsenides, apart from native silver. In addition, native bismuth is associated with silver $[1,4,5]$.

Calcite is the most widespread gangue mineral in the deposits of ore field. Native silver, cobalt and nickel arsenides - cobaltite, scutterudite, schmaltite, safflorite, are predominating ore minerals, which are common both in vein calcite and in hosting rocks. Native silver which is closely associated with arsenides, has various dimensions from small grains up to plates more than $1 \mathrm{~cm}$ in length. Argentite has a subordinated role in ore composition. Because silver is commonly connected to isolated nests small in sizes and rich in grades, there are difficulties in mining such ores. It has led to increasing expenses for exploration activity in the region [1].

Data on enrichment of the Cobalt ore field by native silver give evidence of high silver grades in the ores and concentrates after dressing up to $15-150 \mathrm{~kg} / \mathrm{t}$, and regular grades up to $800-1000 \mathrm{~g} / \mathrm{t}[1,4]$.
At the Gowganda ore field there is a clearer tendency of connecting the richest silver mineralization to veins small in thickness up to $5-15 \mathrm{~cm}$, but the vein stretches are sometimes traced up to $500 \mathrm{~m}$. New series of the ore veins with thickness up to $0.1-2.1 \mathrm{~m}$ and $\mathrm{Ag}$ grades from 187 to $14276 \mathrm{~g} / \mathrm{t}$ is found $[4,5]$ at the Milner sector within the Gowganda ore field.

Arsenides and sulfarsenides of the five-element As$\mathrm{Ni}-\mathrm{Co}-\mathrm{Bi}-\mathrm{Sb}$ association are prevailing in the veins. The veins are enriched in native silver and carbonates, and sulfides, oxides, silicates are common minerals. Besides native silver other native metals are observed here [1] in small amount. Arsenides and sulfarsenides are presented in $\mathrm{Ni}-\mathrm{As}, \mathrm{Ni}-\mathrm{Co}-\mathrm{As}, \mathrm{Co}-\mathrm{As}, \mathrm{Co}-\mathrm{Fe}-\mathrm{As}$ and $\mathrm{Fe}-\mathrm{As}$ associations, and they are connected to special segments of the veins. In the deposits silver is typically associated with arsenides $[1,4,5]$. Rich ores are developed in some part of the veins, which contain $\mathrm{Ni}-\mathrm{Co}-\mathrm{As}$ and $\mathrm{Co}-\mathrm{As}$ association of minerals, and are characterized by silver grades from 15 up to $150 \mathrm{~kg} / \mathrm{t}$. Second-rate ores (from 6 up to $30 \mathrm{~kg} / \mathrm{t}$ ) occur in $\mathrm{Co}-\mathrm{As}$ and $\mathrm{Co}-\mathrm{Fe}-\mathrm{As}$ associations. Low quality ores (from 1.5 up to $15 \mathrm{~kg} / \mathrm{t}$ ) are typical for $\mathrm{Fe}-\mathrm{As}$ and $\mathrm{Ni}-\mathrm{As}$ associations (Fig. 4).

Ore minerals and their associations. Ore minerals tend towards the contacts between silicate and carbonate aggregates and most common ones are located near salbands. Arsenides, sulfarsenides and antimonites are the main ore minerals in the Cobalt-Gowganda deposits.

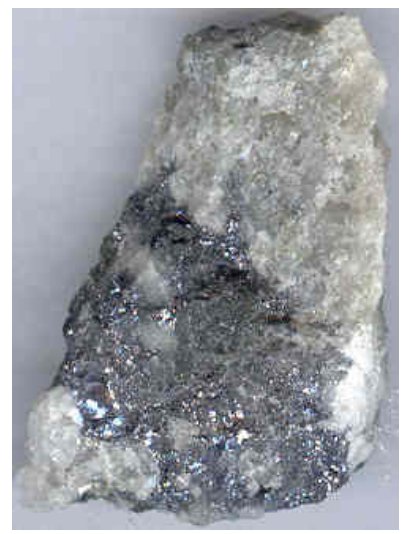

$a$

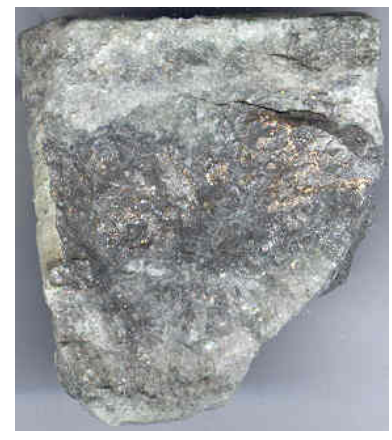

$c$

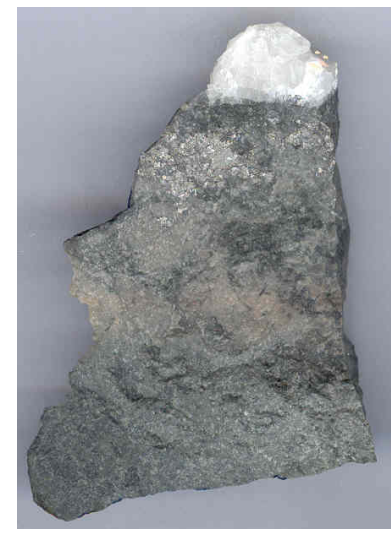

$b$

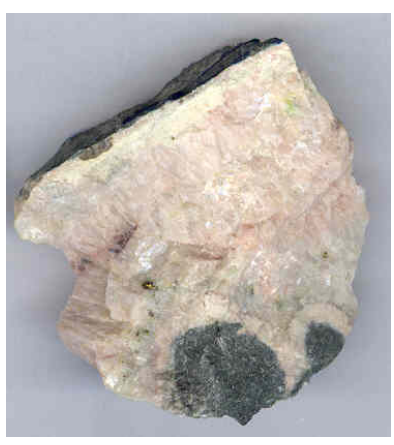

$d$
Fig. 4. Typical ores in veins of the Cobalt-Gowganda region:

$a, b-$ gersdorphite-rammersbergite-clinosaflorite; $c-$ gersdorphite-rammersbergite-cobaltine; $d$-dolomite veins 
Sulfides and sulfasalts occur in carbonate silver-arsenide veins. Apart from wide developed native silver, other silver minerals - allargentum and discrasit are found.

Ore minerals are distributed in the veins as banded concentrations, dissipated disseminations, and often as solid masses (Fig. 4), which make the most part of vein volumes. Small amounts of hematite, magnetite, rutile, anatase, ilmenite and wolframite are available in the vein as well.

Sulfides commonly compose veins and separate grains, form colloform isolations within ore veins and hosting rocks. Sometimes, veins completely filled with sulfides (chalcopyrite, galenite, pyrite, sphalerite, and others) are detected. Besides sulfides determined during our research works, marcasite, tetrahedrite, stefanite,

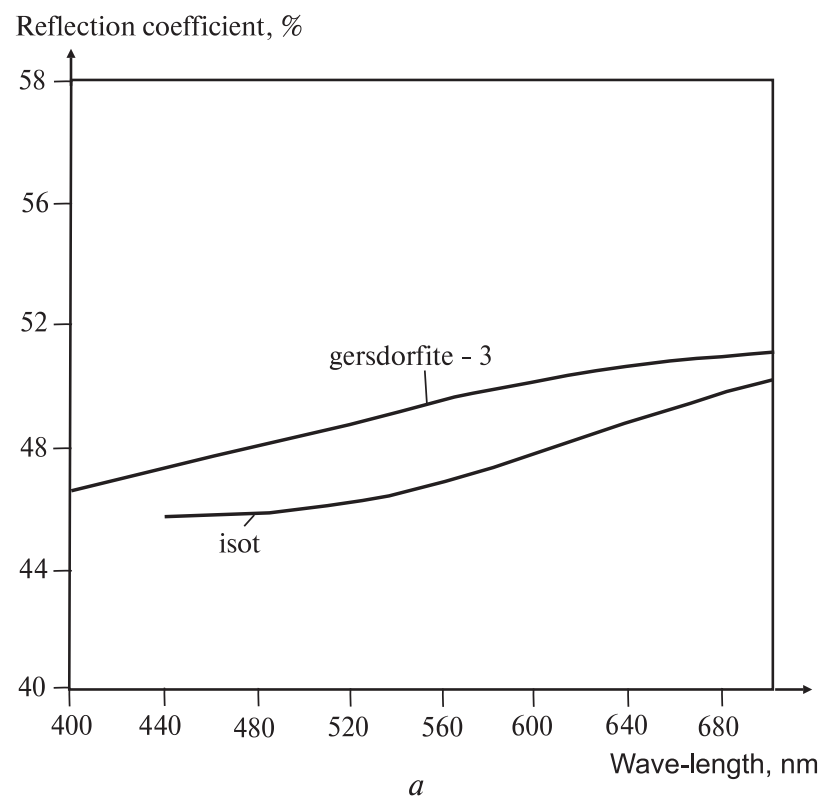

Reflection coefficient, \%

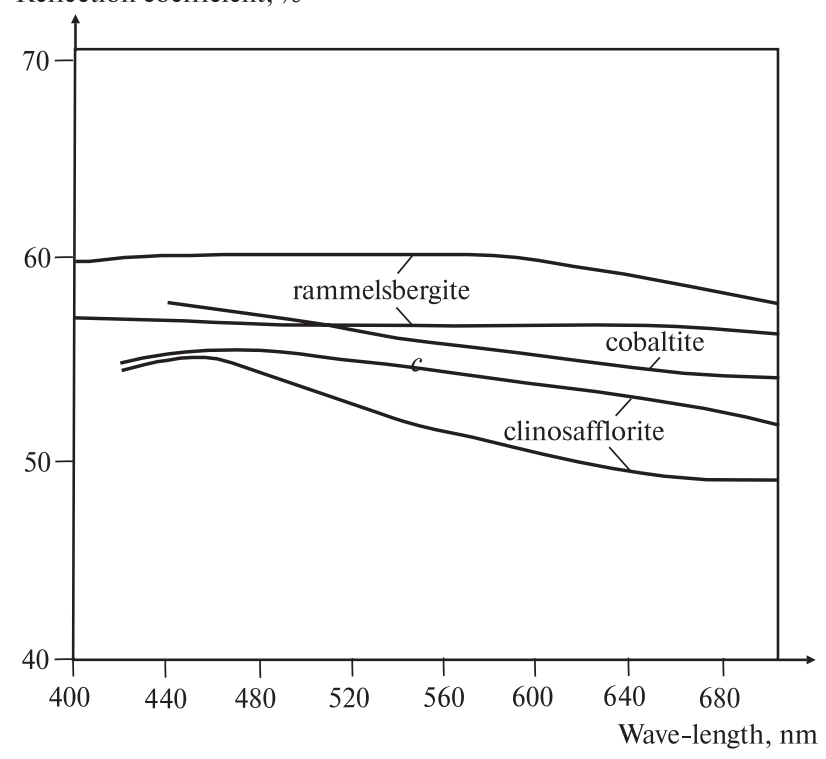

$c$ pyrargyrite, acantite, bornite, chalkozyn, shtrometryt, proustite, polibasite, molybdenite, covellite, samsonite, bismuthine, galena-bismuthine, cobalt-pentlandite, pyrrhotite, bravoite, pavonite, matildite, xantokonit, freieslebenite, smitit, zigenite, larosit, strometrite, mckinstryite, wittichenite, paokerite were discovered after numerous previous investigations [1, 4, 5].

Arsenides are the main minerals of the veins and form $\mathrm{Ni}-\mathrm{As}$, Ni-Co-As, $\mathrm{Co}-\mathrm{Fe}-\mathrm{As}, \mathrm{Co}-\mathrm{As}$ and $\mathrm{Fe}-\mathrm{As}$ associations.

Minerals of $\mathrm{Ni}$-As association - arsenides of nickel, are developed as solid masses, botryoidal isolations, rosettes, and layers. The bulks of solid masses are composed by rammelsbergite, cobaltite, gersdorffite (Fig. 5), parammelsbergite (Fig. 5), nickeline, scutterudite, saf-

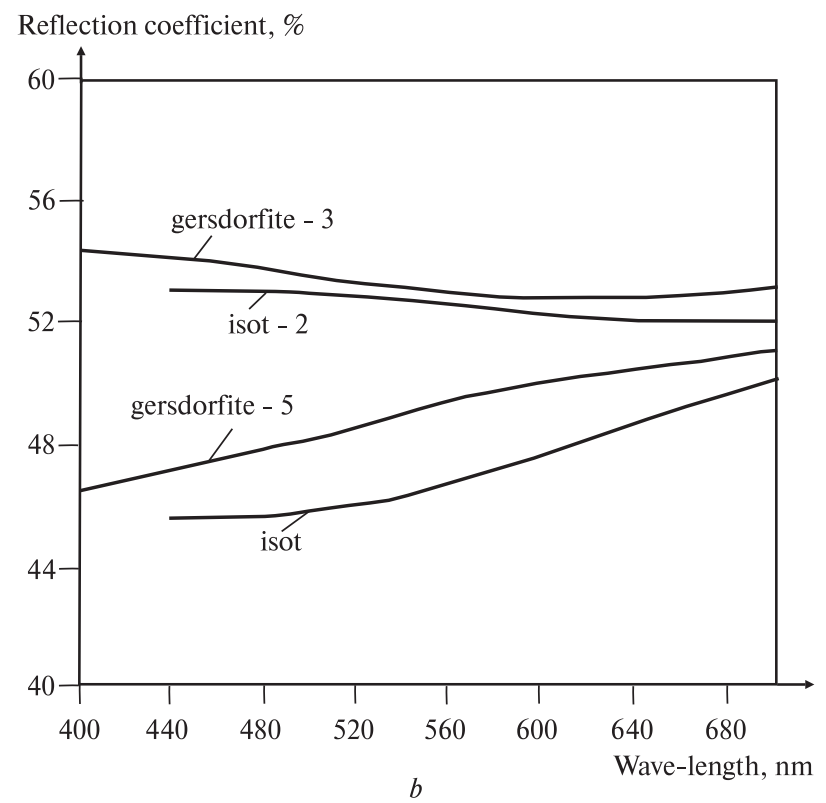

Reflection coefficient, \%

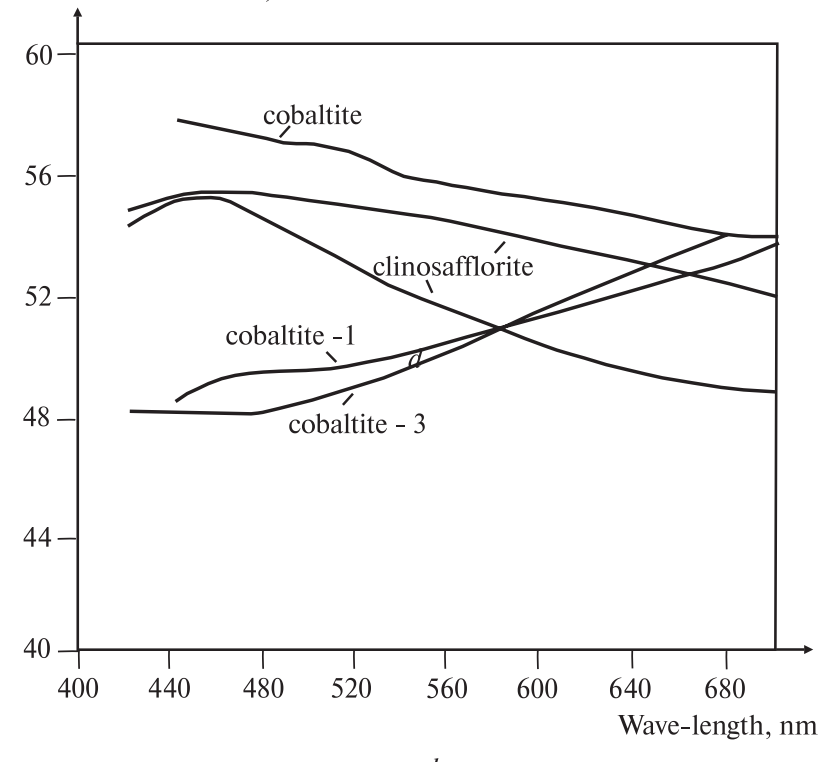

$d$

Fig. 5. Typical reflection specters of the main ore minerals from the Cobalt-Gowganda region:

$a$ - gersdorfite from monomineral ore aggregates; $b$-different generations of gersdorfite from monomineral aggregates; $c-$ rammelsbergite in association with cobaltite and clinosafflorite; $d$-clinosafflorite in association with different cobaltite generations 
florite and ulmannite, and cobaltite, safflorite and nickeline with inclusions of breitgauptite, which are filled with cluster aggregates. Insignificant part of the solid masses is monomineralic, and veins with late nickeline, cobaltite, and sulfides are detected here. Botryoidal isolations have dimensions from 2 up to $8 \mathrm{~cm}$, and are composed by concentric layers of pararammelsbergite, nickeline, rammelsbergite, cobaltite and safflorite. Arsenides of cobalt (cobaltite and safflorite) are developed on external zones of layers, and pararammelsbergite within of cores.

Rosettes (with the size up to $6 \mathrm{~mm}$ ) sometimes include small nickeline and cobaltite cores, inner layers of rammelsbergite, middle layers of cobaltite and nickeline, and narrow outer layers of safflorite. In other cases rosettes are composed by rammelsbergite with surrounding of safflorite.

Mineral layers in most cases are represented from the center to hosting rocks by regulating order of cobaltite, nickeline, rammelsbergite, safflorite, and arsenopyrite. Sometimes pararammelsbergite are detected as big euhedral crystals, and cobaltite is partly replaced by gersdorffite, which closely intergrow with rammelsbergite. Nickeline and cobaltite veins, which are partly replaced by gersdorffite, have been found along boundaries between calcite grains and surrounding chlorite inclusions in calcite.

Minerals of $\mathrm{Ni}-\mathrm{Co}-\mathrm{As}$ association develop in some veins among minerals of $\mathrm{Ni}-\mathrm{As}$ and $\mathrm{Co}-\mathrm{As}$ associations, and are characterized by prevalence of nickel and cobalt arsenides re-settling with $\mathrm{Ni}-\mathrm{As}$ associations, and pararammelsbergite with $\mathrm{Co}-\mathrm{As}$ associations. Among minerals of this association native silver often occurs. Silver from nickeline veins is observed as native silver or coexisting of native silver and allargentum, which is also known as " $\mathrm{Ag}-\mathrm{Sb}$ " minerals. In veins with pararammelsbergite, native silver is common. Within aggregates of $\mathrm{Ni}-\mathrm{Co}-\mathrm{As}$ mineral associations there occurs nickeline as late, often concentric-zonal rosettes with safflorite, cobaltite, sometimes scutterudite, which are surrounded by cobaltite layers from place to place, and as veins and dissipated inclusions in carbonates. The rosettes are presented as dissipated isolations and cluster grains, often surrounded by " $\mathrm{Ag}-\mathrm{Sb}$ " minerals, and they contain their veins with pyrargyrite, stefanite, tetraedrite and aconite.

Late vein nets and xenomorphic grains within carbonates are filled by "Ag-Sb" minerals from a quarter up to half - nickeline, breitgauptite, cobaltite and safflorite, which form ores rich in silver.

In ores of the $\mathrm{Ni}-\mathrm{Co}-\mathrm{As}$ associations native pure silver occurs in cores of the rosettes, which often decorated by scutterudite, and sometimes is coexisting with it as a graphic pattern-structure.

Among minerals of the $\mathrm{Co}-\mathrm{Fe}-\mathrm{As}$ association significant amount of arsenopyrite is determined together with scutterudite, cobaltite, safflorite and alloclasite as rosettes, collomorphic grains and disseminated grains in carbonates. In the rosettes big arsenopyrite crystals and its fine-grained veins are sometimes detected. Dissipated grains in a few of microns of size are represented by scutterudite and cobaltite. Collomorphic isolations include arsenides up to a few centimeters in size in form of orderly distributed layers. Each layer is filled by scutterudite (with small amount of cobaltite, arsenopyrite, and safflorite) dendrites which are oriented radially.

Minerals of the Co-As association occur in the most veins and are characterized by higher content of arsenides of cobalt. Arsenides are presented in forms of rosettes and xenomorphic grains, which are intergrown into solid masses, and dissipated grains within carbonates.

Safflorite layers are composed by prismatic crystals, oriented radially surrounding cores of rosettes. In some cases safflorite coexists with cobaltite and scutterudite, in other places it forms rims surrounding cobaltite and arsenopyrite. In some places scutterudite is partly replaced by tetraedrite, safflorite and other minerals. These minerals are represented by xenomorphic grains and veins, sometimes dendrites, graphic intergrowths. Dendrites occurrence within fine-grained scutterudite gives evidence of big crystals formation due to recrystallization of their small varieties. Arsenopyrite of the CoAs association form euhedral crystals into rosettes as well as within veins which cut the rosettes. Calcite, silver, acantite, pyrargyrite, tetrahedrite, bornite, and calcite with disseminated grains of arsenides and sulfides, and small amount of nickeline vains, are common minerals of the rosettes.

The minerals of the $\mathrm{Fe}-\mathrm{As}$ associations feature high arsenopyrite content and very little volumes of other arsenides (scutterudite, cobaltite, lelingite and safflorite). Arsenopyrite occurs as separated crystals, solid masses or collomorphic isolations. Some crystals are zonal, and some are rimmed by lollingite. Native bismuth veins, galena and marcasite are detected within the arsenides, and sometimes the latter are determined as relic into arsenopyrite or disseminated grains in carbonates. Scutterudite of the $\mathrm{Fe}-\mathrm{As}$ association often rims cobaltite.

Native metals in the veins are represented by native silver, bismuth, gold and arsenic, but only silver amounts are significant. Silver is associated mainly with arsenides, but sometimes native silver is located outside an arsenic mineralization zone or is associated with sulfides. In association with arsenides native silver forms cores of rosettes, veins and disseminated grains in carbonates and arsenides. Silver as cores of rosettes is presented among the $\mathrm{Ni}-\mathrm{Co}-\mathrm{As}$ and $\mathrm{Co}-\mathrm{As}$ mineral associations, which form elongated zones of the high quality ores. Veins and disseminated grains of native silver are presented as rule along all length of veins mostly in the $\mathrm{Ni}-\mathrm{Co}-\mathrm{As}, \mathrm{Co}-\mathrm{As}$ and $\mathrm{Co}-\mathrm{Fe}-\mathrm{As}$ associations. Silver veins occur along borders between the veins and hosting rocks as well as along boundaries of grains. In the arsenic mineralization zone silver is determined as a net-like system of veins or disseminated grains in calcite.

Native silver is also found as big grains, which are possible to determine visually. Silver veins in calcite, disseminated small grains in arsenides, and big (up to $5 \mathrm{~mm}$ ) silver inclusions in calcite have been studied $[1,4,5]$. 
Small amounts of tetrahedrite, arsenopyrite, galena, chalcopyrite, acantite, pyrargyrite, stefanite and other sulfides are associated with this kind of the ores. A little number of silver occurs together with sulfides, detected as glume of sulfides, and as sib-micro inclusions within acantite.

Small quantity of native bismuth is presented in most associations in numerous veins as crystalline grains within silver and bismuth-silver veins. Bismuth is commonly located into lower parts of the veins in associations with $\mathrm{Co}-\mathrm{Fe}-\mathrm{As}$ and $\mathrm{Fe}-\mathrm{As}$ minerals and sulfides. Native arsenic was found only in special kind of ores rich in arsenic $\mathrm{Co}-$ As association at the deposit of Konicil, Cobalt. Native gold is also very rare mineral and it was found within some sectors of the silver deposits [1].

Gangue minerals and its associations. Carbonates and silicates are the main gangue minerals in the CobaltGowganda region. Commonly, carbonates are the main components of the veins, while silicates develop along salbands as thin edgings with thickness up to a few millimeters. Silicate and carbonate parageneses from near the vein halo and within the veins are analogous. Development of feldspars is the most typical metasomatic alteration of the rocks, and can be detected after albite appearance in the Nipissing diabase, sporadic potassium feldspar developing in the Archean volcanic rocks.

Carbonates make the great bulk of the dolomite veins and small calcite veins. Dolomite veins are developed within the Huronian sediments, Kivatin volcanic rocks, and Nipissing diabase and the most ore beds. Besides dolomite, ore minerals, chlorite and calcite, separate calcite crystals, quartz and pyrite are presented here. Calcite forms big romboedric and scalenoedric crystals with sugar like structure and quartz, dolomite and chlorite inclusions. Some big euhedral crystals are black in color due to arsenides inclusions. Calcite small veins are commonly connected to borders between dolomite veins and the hosting rocks, and differ from the dolomite veins due to fine chlorite layers.

Silicates are represented by quartz, chlorite, amphiboles, epidote, albite, and potassium feldspar. They form fine rims along the salbands. Sometimes, small amounts of titanite, allanite, apatite, anatase, stilpnomelane, prehnite, garnet, REE silicates are also observed.

Physical properties of ore minerals from the cobaltsilver ores. Thermo electro-motive force has been measured in pyrite grains from different kinds of ores on five polished samples with a minimal number of measuring 32 for each sample and total amount of 160 indices. The error in the measurement is about $10 \mathrm{mkV} /$ degree. The data obtained show n-type of the observed pyrite with electronic conductivity ( -293 up to $-28 \mathrm{mkV} /$ degree). Based on the results of the measurement, a histogram of obtained data spreading frequency was constructed (Fig. 6). According to the diagram measured indices are uniform (all data are negative numbers) and give evidence of one pyrite generation occurrence.

Pyrite is the most developed ore mineral in the Middle Prydniprovia district (Precambrian Ukrainian Shield $[2,6]$ ), which is a possible area of ore manifesta-

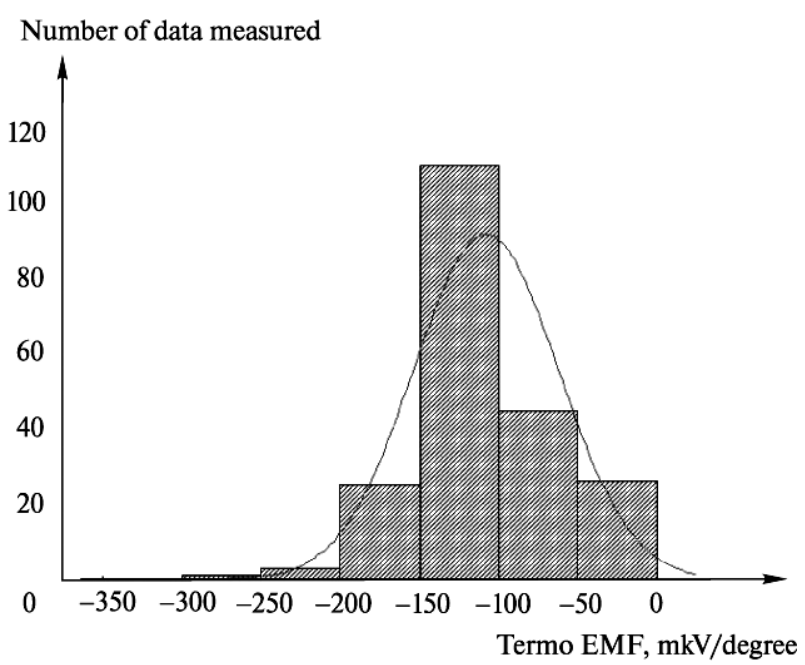

Fig. 6. Histogram of distribution termo-EP data of pyrite from the Cobalt deposit

tions similar to deposits of the five element formation in the Cobalt-Gowganda region. In sedimentary-volcanic sequences of the Sura, Verkhivtsevo, Chortomlyk, Bilozersk, and Orikhovo-Pavlohrad structures native silver together with a number of minerals, which are typical for deposits of the five element formation, were found $[2,3,7]$. Associated with these minerals pyrite from the Verkhivtsevo structure is characterized by electron, hole, and mixing conductivity. Pyrite from metasomatites of the Sura structure has electron conductivity in the outer zones, hole conductivity within inner zones, and mixing conductivity in gold-bearing sectors $[2,3]$. Such broad variations of the pyrite characteristics from the Middle Prydniprovia district give evidence of its heterogeneities and numerous transformations in contrast to pyrite from the Cobalt-Gowganda region.

Reflection specters are regarded as important diagnosis characteristic for ore minerals. The most indicative reflection specters in visible intervals were determined for metals and some semiconductors (sulfides and arsenides, rich in metal), which have metallic or mixed metal and covalent bonds. Reflection specters are regarded as important diagnosis characteristic for ore minerals.

Reflection specters are regarded as important diagnosis characteristics for ore minerals. The most indicative reflection specters in visible intervals were determined for metals and some semiconductors (sulfides and arsenides, rich in metal), which have metallic or mixed metal and covalent bonds. Reflection abilities of the main ore minerals from the Cobalt-Gowganda region (Fig. 5), besides confirmations of its primary diagnostic, were used to determine their differences in separate generations. The obtained data showed repeated origin of the ore minerals and phased character of the ore formation.

Peculiarities of deposits formation and source of metals in the ores. Ore veins of the Cobalt-Gowganda region have been originated during repeared formation of cracks, faults, and breccia. They are after-diabase in geological age, because they have developed both in the 
older sedimentary rocks and in the younger Nipissing diabase. It is considered that [4] diabase sills were mainly a suitable environment for fault ore formation during activations of the regional faults. High quality ores are dominantly connected to veins with steep dip while amount of the ore minerals is very low in cutting its sloping veins although their compositions are similar. Mineralogical-geochemical peculiarities of the vein composition and altered hosting rocks are indicative of providing carbon dioxide, $\mathrm{Ca}, \mathrm{Na}, \mathrm{K}, \mathrm{Ag}, \mathrm{As}, \mathrm{Sb}, \mathrm{Co}$, $\mathrm{Pb}$, TREE, in some cases $\mathrm{Au}$ and $\mathrm{Hg}$ by hydrothermal fluids, and taking out $\mathrm{Fe}, \mathrm{Mg}, \mathrm{Zn}, \mathrm{B}$, Li, Se from hosting rocks $[1,4,5]$.

Temperature and pressure parameters of mineral formation processes occurred under $600 \mathrm{kbar}$ and from 300 up to $350{ }^{\circ} \mathrm{C}$. Ore-bearing fluids as heterogeneous brines have concentrations up to $54 \%$ equivalent of $\mathrm{NaCl}$. Fluid inclusions in quartz and calcite from orebearing and barren-rock veins the Cobalt-Gowganda region form five different types with various combinations and ratio of liquid, gas and solid (crystalline) phases. The histograms of homogenization temperatures of the inclusions from all ore associations group them into areas of 100,230 and $330{ }^{\circ} \mathrm{C}$ with the total limits from 100 up to $560{ }^{\circ} \mathrm{C}$ [1]. Interestingly, these investigations did not show carbon dioxide inclusions, although carbonates are the main minerals in the veins. Increasing $\mathrm{pH}$ fluid as a result of its boiling up and carbon dioxide separation, which occur under periodical sharp falls of pressure due to fault and crack formation, is the main reason for metal deposition.

There is a constant spatial relationship of deposits and hosting rocks with high concentrations of $\mathrm{Co}, \mathrm{Ni}$, Ag (amphibolite, diabase, etc.). Inheriting of elements, minerals and isotopic compositions of surrounding rocks by veins, mobilization of metals and formation of its negative anomalies within near ores zones, differences in geological time of the intrusive formation and ore forming process, simultaneous moving off the same elements from hosting rocks, earlier hydrothermal formations, and depositing its within veins [7-9] are the main evidence of the statement concerning utilization of the metals from surrounding rocks as the leading mechanism in ore formation. To understand the origin of ore concentrations in the deposits of the five-element formation better, we need to compare peculiarities of ore formations in spatially different ore fields with different quantity of metals in ores and hosting rocks. In this sense, absence of uranium minerals in the deposits of the Cobalt-Gowganda region under very low uranium concentrations in surrounding rocks and minerals can be determinant for nature of mineralization.

Famous vein deposits of the five-element formation in the Czech massive (for example, Jachimov, Iohangeorgenshadt) as analogous of the deposits in the Cobalt-Gowganda region, have similar geological and structural positions of mineralization. The deposits of the Czech massive are connected to ekzocontacts of granites and Proterozoic - Lower Paleozoic rocks [8-10]. Numerous investigations have also shown similarity in morphology of ore beds and its location, ore mineral associations and others. Apart from these facts, there is also difference in metallogenic trend due to presence of basic rocks and schist rich in organic material and sulfides in the Czech deposits [1, 8, 10]. During intensive alteration of the surrounding rocks significant part of uranium and associated metals was transformed into mobile form and determined high dispersions of ore components in similar rocks, removing some of them from creation of its negative anomalies.

By the lack of uranium minerals in ore mineral associations in the Cobalt-Gowganda region we can make conclusions regarding important role of primary uranium concentrations in the initial rocks. In the CobaltGowganda there is exceptional low uranium grade of uranium in the hosting rocks which caused the main difference between deposits of the five-element formation in Europe [8, 9] and Canada [4].

For minerals of Ag-Co-Ni sulfarsenides deposits of the Cobalt-Gowganda ore region there is typical relatively invariable composition of the light stable isotopes. $\delta^{18} \mathrm{O}$ values in quartz are commonly between $11.1-$ $16.0 \%$, in potassium feldspar $-10.1-123 \%$, in albite $-8.1-14.4 \%$, in actinolete $-6.0-7.6 \%$, in chlorite $-3.2-5.6 \%$, and $\delta \mathrm{D}$ in chlorite are variable from -42 up to $35 \%$ [1, 4]. Ore forming hydrothermal fluids are characterized by isotopic compositions of $\delta^{18} \mathrm{O}$ from 2.5 up to $5 \%$, and $\delta \mathrm{D}$ from -40 up to $+5 \%$. Such values are typical for isotopically and geochemically borrowed brines from the Huronian water-bearing horizons, which eventually occurred as a result of sea pores fluids due to over flow by the Proterozoic meteoric waters. It is in accordance with strontium isotopic composition in actinolites $\left({ }^{87} \mathrm{Sr} /{ }^{86} \mathrm{Sr}-0.715-0.729\right)$, and is a clear indicator of its formation from the Huronian sedimentary reservoir [1].

Isotopic compositions of quartz from silicate filling, bulk samples and veins with carbonates domination are intimated, and, therefore, we can suppose primary carbonate sedimentation from fluids with similar isotopic characteristics to fluids which brought silicates precipitation under the close temperatures. Vein dolomites with $\delta^{18} \mathrm{O}$ values from 21 up to $23.1 \%$, were deposited under $110-140{ }^{\circ} \mathrm{C}$, while vein calcites with $\delta^{18} \mathrm{O}$ values from 1.7 up to $15.7 \%$, indicate late flows of meteoric waters. We determined exactly the same $\delta^{18} \mathrm{O}$ values due to isotopic investigations among vein calcite majority independent of native silver occurrence in the veins and from thickness of its veins. In spite of all this we should note clear divergence $\delta^{18} \mathrm{O}$ values of the vein calcites from the values which are typical for carbonates of massive layer carbonate rocks of sedimentary origin.

The $\delta^{13} \mathrm{C}$ values for vein carbonates are grouped in limits from -3.1 up to $-5.3 \%$ and it is evidently close to data for isotopic carbonate marks of the hydrothermal fluid. Detected differences of $\delta^{13} \mathrm{C}$ data for vein carbonates within $2-2.5 \%$ are not related to occurrence of ore minerals, which are associated with the carbonates, and, therefore, they reflect total evolution of hydrothermal fluids composition.

Conclusions. Achaean volcanic basement with steep dipping of the rocks is the oldest structural element of 
the Cobalt-Gowganda region. It is discordantly covered by the Proterozoic sediments with flat bedding. Both of these sequences are intruded by diabases with sill-like shape. Tectonic stability of the region has occurred since the Early Proterozoic.

About $80 \%$ of ore-bearing veins with average thickness of $10-15 \mathrm{~cm}$, are deposited within rocks of the Cobalt suit, and other are connected to the Nipissing diabase and Kivatine suit. Silver bearing veins are located above and below the Nipissing diabase as well as within the diabase. Diabase did not have an ore forming ability for veins, which are post diabase in origin.

Cobalt and nickel arsenides and native silver prevail among ore minerals. Cobaltite, scutterudite, shmaltine, and safflorite develop in the vein calcites and in the hosting rocks. Significant part of native silver is connected to widely distributed $\mathrm{Ni}-\mathrm{Co}-\mathrm{As}$ and $\mathrm{Co}-\mathrm{As}$ mineral associations, which are characterized by high amounts of parammelsbergite, cobaltite and saflorite. Calcite is the most developed vein mineral in deposits of the Cobalt ore field.

Determinations of thermo electro-motive force have shown n-type of the observed pyrite with electronic conductivity. Homogeneity of the data indicates that the main pyrite masse was formed in relatively similar conditions in contrast to the possible analogous deposits of the five-element formation in the known sectors in the Ukrainian Shield, where pyrite from silver-bearin associations is heterogeneous.

Increasing $\mathrm{pH}$ fluids due to their boiling up and carbon dioxide separation, under periodical sharp abatement of pressure during faults formation and cracks development, are the main reason of metals deposition. Hosting rocks are regarded as a dominated source of the metals from industrial deposits. Active fluids leached of the main ore components from the surrounding rocks, some of them formed ore beds and other part moved away from ore forming systems. Various ore peculiarities in the ore world fields have been caused by different geochemical and mineralogical specialization of hosting rocks.

Acknowledgments. We thank Prof. G. Skippen (Carleton University, Ottawa, Canada) and the geologists of the Geological Survey of Canada (Ottawa, Canada) for help and assistance in visits and observations of the Cobalt-Gowganda region deposits.

\section{References.}

1. Joyce, D. K., Tait, K., Vertoli, V., Back, M. and Nicklin, I., 2012. The Cobalt Mining District, Cobalt, Ontario, Canada. Mineralogical Record, 43(6), pp. 685-713. 2. Nechaev, S. V. and Syomka, V. O., 2012. Ore-bearing metasomatites of central part of the Ukrainian Shield (prognostic, prospecting and general geological significance). Geochemistry and ore formation [pdf], 31-32, pp. 12-23. Available at: <http://igmof.org.ua/sites/default/files/4_3.pdf $>$ [Accessed 22 September 2017].

3. Nechaev, S. V., 2011. Silver and gold of the Perga ore hub. Geologist of Ukraine, 1(33), pp. 90-104.

4. Duplessis, C., Takara Resources Inc., 2015. Castle Silver Property, Gowganda, Ontario, Canada. Technical
Report NI 43-101 dated July $9^{\text {th }} 2015$ for Takara Resources Inc. \& Gold Bullion Development Corporation incompliance with № 43-101 and Form 43-101 F1 [pdf]. Available at: <http://www.nisa.net/takara/TakaraCastlesilverminestechreport2015_0709.pdf $>$ [Accessed 5 August 2017].

5. Nankamba, P. and Burden, L. D., 2016. 43-101F1 Technical Report Aldershot Resources Ltd., Haultain Property, Haultain, Nicol, Milnerand Van Hise Townships, Ontario (NTS 41P10) [pdf]. Available at: <http:// www.aldershotresources.com/wp-content/uploads/2016/11/ALZ-tech-report-1116.pdf> [Accessed 17 November 2017].

6. Verkhovtsev, V. H. and Yuskiv, Yu. V., 2016. Prospecting points of studying geostructures of the Ukrainian Shield and its slopes which are active at the latest stage development. Ukrainian Journal of Remote Sensing, 8, pp. $40-50$.

7. Kovalchuk, M.S., Kroshko, Yu. V. and Shestakov, O. Yu., 2016. Gold, silver and copper in the weathering crust of the Yuriivske gold deposit (Kyrovohradskyi Block, Ukraine. Heolohiia ta rudonosnist Ukrainy, 1(2), pp. 17-24.

8. Dahlkamp, F. J., 2016. Uranium Deposits of the World. Europe. Berlin, Heidelberg: Springer-Verlag Europe.

9. Breiter, K., 2014. 800 years of mining activity and 450 years of geological research in the Krušné Hory. Boletim do Museu Paraense Emílio Goeldi. Ciências Naturais, Erzgebirge Mountains Central Europe, 9(1), pp. 105-134.

10. Burisch, M., Gerdes, A., Walter, B., Neumann, U., Fettel, M. and Markl, G., 2017. Methane and the origin of five-element veins: Mineralogy, age, fluid inclusion chemistry and ore forming processes in the Odenwald, SW Germany. Ore Geology Reviews, 81(1), pp. 42-61.

\section{Особливості геолого-структурного положення, речовинного складу й походження сріблоносних руд району Кобальт-Гоугенда (Канадський щит)}

\section{В. М. Гулій, О. В. Костюк}

Львівський національний університет імені Івана Франка, м. Львів, Україна, e-mail: vgul@ukr.net; apxеоресурс@ gmail.com

Мета. Отримання нових і узагальнення опублікованих результатів вивчення геолого-структурного положення, речовинного складу та особливостей утворення руд родовищ п'ятиелементної формації району Кобальт-Гоугенда (Канада), порівняння їх із подібними родовищами, що розташовані в інших регіонах світу.

Методика. Включала традиційні геологічні спостереження з відбором зразків окремих різновидів вміщуючих порід і руд, мінералого-петрографічне вивчення шліфів і аншліфів з онтогенічними побудовами послідовності формування мінералів і виділення окремих їх генерацій, визначення хімічного складу порід і мінералів з оцінкою їх відбивної здатності й термоелектрорушійної сили сульфідів. Для 
генетичних побудов проведено ізотопний аналіз вуглецю й кисню карбонатів району родовищ.

Результати. Результати, отримані при дослідженні особливостей геологічної будови району, положення рудних тіл, мінерального складу руд дають змогу пов'язати виникнення рудної мінералізації району Кобальт-Гоугенда з основними етапами геологічного становлення зеленокам'яного поясу Абітібі, розвитку системи розломів різного порядку й тріщин, що забезпечували циркуляцію рудоносних розчинів, які збагачувались окремими компонентами зі вміщуючих порід. Видовий склад і розмаїття мінералів у кожному конкретному випадку просторової локалізації зруденіння визначались, переважно, складом і будовою вихідних вміщуючих порід.

Наукова новизна. Полягає у створенні цілісної характеристики родовища п'ятиелементої формації району Кобальт-Гоугенда з відображенням різних генерацій рудних мінералів, що супроводжуються різнорідними фізичними характеристиками й значеннями ізотопного складу вуглецю й кисню карбонатів, які вирізняють їх від карбонатних порід інших генетичних типів.

Практична значимість. Визначається отриманими характеристиками еталонних родовищ срібла та мінералів різних асоціацій, що дозволяють оцінювати ймовірні знахідки подібних об'єктів в аналогічних комплексах Українського щита.

Ключові слова: родовища срібла, п'ятиелементна формація, Кобальт-Гоугенда, Канадський та Український щит

\section{Особенности геолого-структурного положения, вещественного состава и происхождения сереброносных руд района Кобальт-Гоугенда (Канадский щит)}

\section{В. М. Гулий, О. В. Костюк,}

Львовский национальный университет имени Ивана Франко, г. Львов, Украина, e-mail: vgul@ukr.net; apxeopecypc@gmail.com

Цель. Получение новых и обобщение опубликованных раньше результатов изучения геологоструктурного положения, вещественного состава и особенностей образования руд месторождений пятиэлементной формации района Кобальт-Гоугенда (Канада), сравнения их с похожими месторож- дениями, которые расположены в других регионах мира.

Методика. Включала традиционные геологические наблюдения с пробоотбором определенных разновидностей вмещающих пород и руд, минералого-петрографического изучения шлифов и аншлифов с онтогеническими построениями последовательности формирования минералов и выделения отдельных их генераций, определения химического состава пород и минералов с оценкой их отражательной способности и термоэлектродвижущей силы сульфидов. Для генетических построений проведен изотопный анализ углерода и кислорода карбонатов района месторождений.

Результаты. Результаты, полученные при исследовании особенностей геологического строения района, положения рудных тел, минерального состава руд позволяют связать возникновение рудной минерализации района Кобальт-Гоугенда с основными этапами геологического формирования зеленокаменного пояса Абитиби, развития систем разломов разного порядка и трещин, которые способствовали циркуляции рудоносных растворов, обогащенных отдельными компонентами вмещающих пород. Видовой состав и разнообразие минералов в каждом конкретном случае пространственной локализации орудинения определялись, преимущественно, составом и строением исходных вмещающих пород.

Научная новизна. Заключается в создании целостной характеристики месторождения пятиэлементной формации района Кобальт-Гоугенда с отображением разных генераций рудных минералов, которые сопровождаются разнородными физическими характеристиками и значениями изотопного состава углерода и кислорода карбонатов, что и отделяет их от карбонатных пород иных генетических типов.

Практическая значимость. Определяется полученными характеристиками эталонных месторождений серебра и минералов разных ассоциаций, которые позволяют оценивать вероятные находки похожих объектов в аналогичных комплексах Украинского щита.

Ключевые слова: месторождения серебра, пятиэлементная формация, Кобальт-Гоугенда, Канадский и Украинский щит

Рекомендовано до публікації докт. геол.-мін. наук Г. М. Яценком. Дата надходження рукопису 06.01.17. 